\title{
Allenols versus Allenones: Rhodium-Catalyzed Regiodivergent and Tunable Allene Reactivity with Triazoles
}

\author{
Benito Alcaide, ${ }^{*[a]}$ Pedro Almendros, ${ }^{*[b]}$ Sara Cembellín, ${ }^{[a]}$ Teresa Martínez del Campo, ${ }^{[a]}$ and \\ Guillermo Palop ${ }^{[a]}$
}

Dedication ((optional))

\begin{abstract}
Pyrrolines and 6-oxo-hexa-2,4-dienals have been prepared through the divergent reactions of 1benzenesulfonyl-4-aryl-1,2,3-triazoles with functionalized allenes. The rhodium-catalyzed reactions between allenols and 1-benzenesulfonyl-4-aryl-1,2,3-triazoles yielded 2pyrrolines. This transformation is compatible with the presence of aliphatic, aromatic, heterocyclic, amide, and
\end{abstract}

halogen functional groups. Interestingly, a reactivity switch took place when the allene-tethered alcohol substrate was replaced by its ketone counterpart. When the rhodiumcatalyzed reaction of 1-benzenesulfonyl-4-phenyl-1,2,3triazole was performed with allenones, acyclic 6-oxo-hexa2,4-dienals were stereoselectively formed as $(2 Z, 4 E)$ isomers.

\section{Introduction}

$N$-Sulfonyl-1,2,3-triazoles are important synthetic intermediates, which have been used as latent $\alpha$-imino metal carbenes for the preparation of a vast array of functionalized organic compounds. ${ }^{[1]}$ On the other hand, despite regioselectivity issues, the allene moiety has attracted much attention due to its chamaleonic reactivity, which results in a variety of synthetically useful transformations. ${ }^{[2]}$ Numerous examples on the metal-catalyzed transannulation reactions of $\mathrm{N}$-sulfonyl-1,2,3-triazoles with different functional groups have been described. However, to the best of our knowledge there is just three reports on the reactivity of this heterocycle with the allene scaffold (Scheme 1a). ${ }^{[3]}$ Taking into account that the intermolecular transannulation reaction reported by Miura and Murakami is limited to simple monosubstituted allenes, ${ }^{\left[{ }^{[b]}\right]}$ we decide to test the reactivity of more functionalized allenes, namely, $a$-allenols and a-allenones (Scheme 1b).
Although catalytic triazole transannulation with 1,2-dienes bearing an additional nucleophilic center is attractive, it may be troublesome due to additional selectivity problems. Herein, we describe the rhodium-catalyzed reactions of 1-benzenesulfonyl-4aryl-1,2,3-triazoles with allene-tethered alcohols or ketones, which provide a divergent synthetic protocol for the construction of 2pyrrolines or 6-oxo-hexa-2,4-dienals through controllable a-imino metal carbene related processes.

E-mail: alcaideb@quim.ucm.es

[b] Prof. Dr. Pedro Almendros

Instituto de Química Orgánica General

Consejo Superior de Investigaciones Científicas, IQOG-CSIC

Juan de la Cierva 3, 28006 Madrid (Spain)

Fax: (+34) 91-5644853

E-mail: Palmendros@iqog.csic.es

Supporting information for this article is available on the WWW under http://www.chemeurj.org/ or from the author. 
R

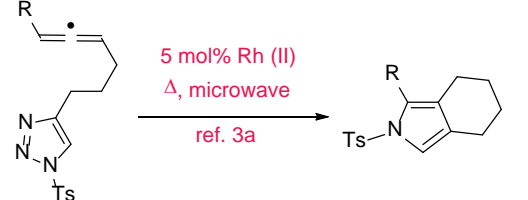

Ts

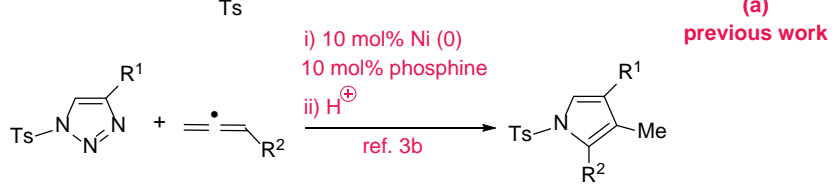

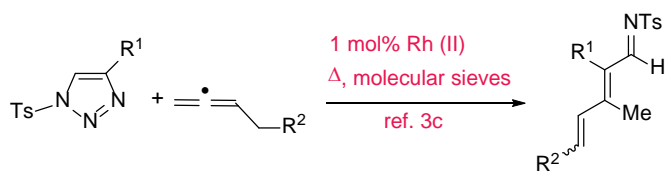

$\overbrace{\mathrm{TS}_{\mathrm{TS}}}^{\mathrm{X}}$

(r)

Scheme 1. Transannulation reactions of $N$-sulfonyl-1,2,3-triazoles with allenes. unidentified products (Scheme 3). Probably, the highly encumbered indolone-tethered allenol $\mathbf{1} \mathbf{j}$ did not afford the 2pyrroline $4 \mathrm{ja}$ because of steric reasons, due to the presence of the tertiary stereocenter proximal to the reactive side. Interestingly, the reactions of allenols $\mathbf{1 k}-\mathbf{m}$ derived from aliphatic aldehydes with triazole $\mathbf{3} \mathbf{a}$ afforded the required 2-pyrrolines $\mathbf{4 k a - m a}$ with a very high selectivity -by our detection method through NMR the other diastereomer could not be detected-, but in moderate yields (Scheme 3). The rhodium-catalyzed reaction between 1-phenyl-1methyl-1,2-propadiene, a 1,1-disubstituted allene which lacks the hydoxy group, and triazole $3 a$ was not very competent and led to a complicated mixture (Scheme 3). In order to know the influence of the hydroxyl group, the allenyl ether $\mathbf{1 b}$-Me derived from protection of the $\mathrm{OH}$ in allenol $\mathbf{1 b}$ was employed (Scheme 3). The absence of the free alcohol has a negative impact in the reactivity because no pyrroline $\mathbf{4 b a - M e}$ was detected when allene $\mathbf{1 b}$-Me was treated with $\mathrm{N}$-sulfonyl-1,2,3-triazole $3 \mathrm{a}$ in presence of $\mathrm{Rh}_{2}(\mathrm{oct})_{4}$. Starting allene $\mathbf{1 b}$-Me remained unreactive after 2 hours (the required time for completion of the reaction of allenol $\mathbf{1 b}$ ), and under prolonged heating the only products observed were derived from decomposition of triazole $\mathbf{3 a}$. Tentatively, the failure of the OMeallene $\mathbf{1 b}$-Me should be attributed to the absence of a beneficial coordinative interaction between the rhodium and the $\mathrm{OH}$ group which is present in allenols such as $\mathbf{1 b}$, presumably in the transient species formed after the attack of the allene moiety to the rhodacarbene. Unfavorable steric reasons may also be operative.

\section{Results and Discussion}

Starting allenols $\mathbf{1 a}-\mathbf{i}$ were easily prepared from the appropriate aldehyde and a conveniently substituted 1-bromo-2-propyne through indium-promoted reaction under Barbier conditions. ${ }^{[4]}$ Allenones $\mathbf{2}$ were readily obtained by oxidation of allenols $\mathbf{1}$ with Dess-Martin periodinane. ${ }^{[5]}$ Initially, we surveyed whether allenol 1a was a competent substrate to be engaged in the metalcatalyzed reaction with $N$-sulfonyl-1,2,3-triazole $\mathbf{3 a}$. This assumption exhibits some troubles and displays an obstacle because of the competitive and well-known O-C cyclization of allenols in the presence of metals. ${ }^{[6]}$ Happily, the $\mathrm{Rh}_{2}$ (oct) ${ }_{4}$ catalyzed reaction proceeded smoothly in toluene at reflux temperature to afford the 2-pyrroline derivative 4aa (Scheme 2) as a separable mixture $(80: 20)$ of diastereomers. The aromatization was blocked by the methyl group at the newly generated quaternary streocenter. Different solvents such as $\mathrm{CHCl}_{3}$ or 1,4dioxane were not as effective as toluene. Poor performance was achieved with the use of different promoters such as $\mathrm{Cu}(\mathrm{OTf})_{2}$ or $\mathrm{AgNTf}_{2}$. When the loading of rhodium salt was augmented from 1 $\mathrm{mol} \%$ to $5 \mathrm{~mol} \%$, it resulted in a negligible yield increasement. Our next ain was to investigate the generality of the 2-pyrroline formation reaction by variation of the allenol substitution pattern. In the event, a variety of allenols were probed to give the nonaromatic heterocyclic products 4aa-ai in reasonable yields (Scheme 2). The stereoselectivities of the reactions of allenols 1ai derived from aromatic aldehydes with triazoles $\mathbf{3} \mathbf{a}, \mathbf{b}$ were found to be modest, and the best result was obtained (selectivity ca. 85:15) from the reactions between allenol-tethered indoles $\mathbf{1 h}$ and 1i with $\mathrm{N}$-sulfonyl-1,2,3-triazole $\mathbf{3 a}$ (Scheme 2). The rhodiumcatalyzed reaction of tertiary allenol $\mathbf{1 j}$ with $N$-sulfonyl-1,2,3triazole $\mathbf{3 a}$ was troublesome, and give a complicated mixtures of 
<smiles>[R]C(=N)C(O)CSn1cc(N)nn1</smiles>

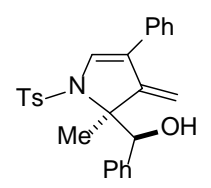

(d.r. $=80: 20)^{[\mathrm{a}]}$ 4aa $(62 \%, 3 h)^{[b]}$<smiles>C=C1C(c2ccccc2)=CN(S)[C@@]1(C)C(O)c1ccc(C)cc1</smiles><smiles>C=C1C(c2ccccc2)=CN([As])[C@]1(c1ccccc1)C(O)c1ccc(C)cc1</smiles>

$$
\text { (d.r. }=70: 30)^{[a]}
$$
4ba $\left(69 \%, 2\right.$ h) $\quad(\text { d.r. }=67: 33)^{[\mathrm{a}]}$

$(\text { d.r. }=67: 33)^{[a]}$
$4 c a(60 \%, 3 h)^{[b]}$<smiles>C=C1C(c2ccccc2)=CN([As])[C@@]1(C)C(O)c1ccc(Cl)cc1</smiles>

(d.r. $=75: 25)^{[\mathrm{a}]}$

4da $(73 \%, 3 \mathrm{~h})^{[\mathrm{b}]}$<smiles>C=C1C(c2ccccc2)=CN(S)C1(c1ccccc1)C(O)c1ccc(Cl)cc1</smiles><smiles>C=C1C(c2ccccc2)=CN([As])[C@@]1(C)C(O)c1ccccc1OC</smiles><smiles>C=C1C(P)=CN([As])[C@@]1(C)C(O)c1ccccc1OC</smiles><smiles>C=C1C(c2ccccc2)=CN(S)[C@@]1(C)C(O)c1cccc(Cl)c1</smiles>

(d.r. $=55: 45)^{[\mathrm{a}]}$

$(d . r .=55: 45)^{[a]}$

(d.r. $=70: 30)^{[a]}$

$4 f b(49 \%, 2 h)^{[b]}$

$(\text { d.r. }=70: 30)^{[a]}$

4ea $(55 \%, 10 h)^{[b]} 4 f a(36 \%, 2 h)^{[b]}$<smiles>C=C1C(P)=CN([As])[C@@]1(C)C(O)c1cccc(Cl)c1</smiles>

(d.r. $=70: 30)^{[\mathrm{a}]}$ 4gb $(62 \%, 2 h)^{[b]}$

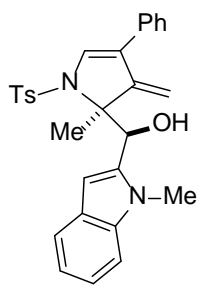

$(\text { d.r. }=85: 15)^{[\mathrm{a}]}$ 4ha $(31 \%, 10 h)^{[b]}$

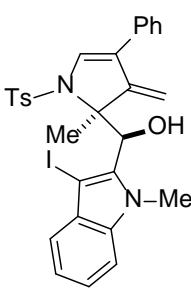

$(\text { d.r. }=85: 15)^{[\mathrm{a}]}$ $4 i a(40 \%, 3 \mathrm{~h})^{[\mathrm{b}]}$
4 ga $(38 \%, 2 h)^{[b]}$

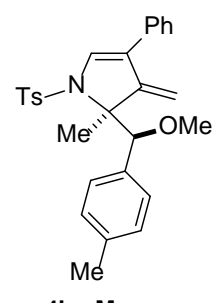

4ba-Me (0\%)
Scheme 2. Rhodium-catalyzed reaction of allenols $1 \mathbf{a}-\mathbf{i}\left(R^{1}=\mathrm{Ar}\right)$ with triazoles 3. Controlled synthesis of 2-pyrrolines 4aa-ia. $\mathrm{PMP}=4 \mathrm{MeOC}_{6} \mathrm{H}_{4}$. [a] The mixture of diastereomers was separated by column chromatography. [b] Major diastereomer shown. Yields refers to major isomer, isolated as pure product with correct analytical and spectroscopic data. Minor isomer could not be isolated as pure material.

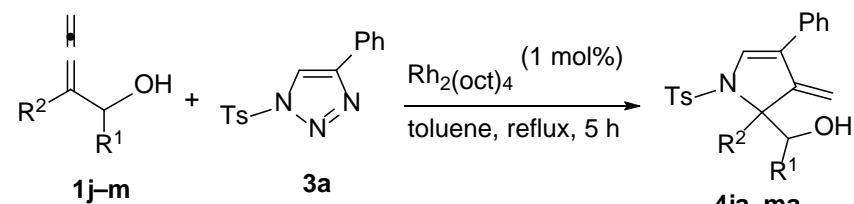

4ja-ma

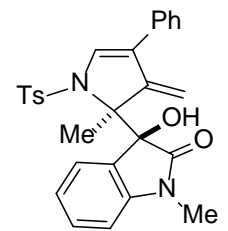

$4 \mathrm{ja}(0 \%)$<smiles>C=C1C(c2ccccc2)=CN([As])[C@@]1(C)C(O)Cc1ccccc1</smiles>

(d.r. $=100: 0)$ 4ka (37\%)<smiles>[B-]N1C=C(c2ccccc2)C(=C)[C@@]1(c1ccccc1)C(O)Cc1ccccc1</smiles>

(d.r. = 100:0) 4la (48\%)<smiles>C=C1C(c2ccccc2)=CN(S)[C@@]1(C)C(O)[C@H]1COC(C)(C)O1</smiles>

(d.r. $=100: 0)$

4ma (41\%)

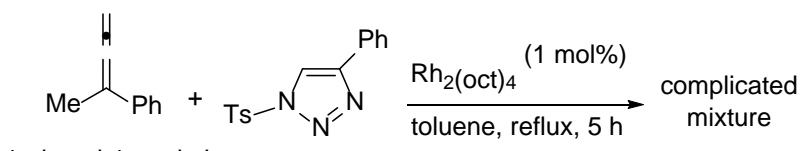

1-phenyl-1-methyl1,2-propadiene

$3 a$

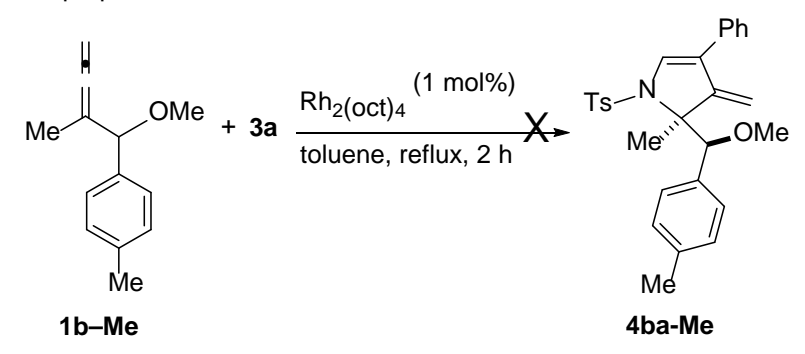

Scheme 3. Rhodium-catalyzed reaction of allenols $1 \mathbf{j}-\mathbf{m}\left(R^{1}=\right.$ alkyl) with triazole 3a. Controlled synthesis of 2-pyrrolines $4 \mathbf{j a}-\mathbf{m a}$.

Having found a reliable method for the synthesis of 2 pyrrolines 4 through the coupling of allenols 1 with $N$-sulfonyl-1,2,3triazoles 3 , we decide to undertake the study of a different type of allenes, namely, allenones $\mathbf{2}$. However, allenones can react under rhodium-, silver-, gold-, and palladium-catalyzed conditions to form new $\mathrm{O}-\mathrm{C}$ bonds through traditional cycloisomerization paths, resulting in furans. ${ }^{[5],[7]}$ Given this established reactivity, we face a potential problem in the form of a rival cyclization reaction. Taking into account the high affinity of rhodium salts toward $\mathrm{N}$-sulfonyl1,2,3-triazoles, we envisioned that the reaction of the azaheterocycle $\mathbf{3}$ with the metallic catalyst should take place first; thus making feasible our synthetic design. Under the optimized reaction conditions for allenols $\mathbf{1}$, complete consumption of the starting allenone $\mathbf{2 a}$ in presence of $N$-sulfonyl-1,2,3-triazole 3a was observed. Noteworthy, lack of formation of the cyclic product of type 4 was observed under $\mathrm{Rh}_{2}(\mathrm{oct})_{4}$ catalysis. In the event, the 1,6-dicarbonyl derivative $\mathbf{5 a}$ was formed instead as single isomer but in a low $25 \%$ yield. Consequently, a notable effect on the outcome of the reaction was evidenced due to the different electronic character of the allene precursor. This initial experiment settled the viability of a substrate-controlled divergent allene reactivity, but the low yield of the final product is a serious limitation for its synthetic utility. Fortunately, the efficiency of the reaction was improved with the modification of the solvent (chloroform rather than toluene). Scheme 4 outlines the preparation of several 6-oxohexa-2,4-dienals 5 . The imine functionality in $\mathbf{5 m}$-imin survived the 
reaction conditions and the chromatographic purification, but the final iminoketone adduct was isaolated in diminished yield. Cycloisomerization adducts, namely, furans were detected in all cases as minor side products (ca. $5 \%$ ) by TLC and ${ }^{1} \mathrm{HNMR}$ analyses of the crude reaction mixtures. Unlike allenols 1, which undergo triazole transannulation reactions, allenones 2 displayed a different type of reactivity, enabling the synthesis of 1,6dicarbonyls $\mathbf{5}^{\left[{ }^{[8]}\right.}$ Adducts $\mathbf{5}$ were obtained in a totally stereoselective fashion as single $(2 Z, 4 E)$ isomers. The structure and stereochemistry of 6-oxo-hexa-2,4-dienal $\mathbf{5 d}$ was unambiguously assigned through its X-ray crystallographic analysis (Figure 1). ${ }^{[9]}$<smiles>[R10]C=NC([R])C([R])=O</smiles>
5a-m-imin<smiles>C/C(=C\C=C\C=O)C(=O)c1ccccc1</smiles>

$$
5 a(47 \%)
$$<smiles>O=C/C(=C\C=C(c1ccccc1)c1ccccc1)C(=O)c1ccc(Cl)cc1</smiles>

$5 e(58 \%)$<smiles>Cc1ccc(C(=O)/C(=C/C=C/C=O)c2ccccc2)cc1</smiles>

5 c $(72 \%)$<smiles>O=C/C(=C/C=C(c1ccccc1)c1ccccc1)C(=O)c1ccccc1</smiles>

5n $(48 \%)$<smiles>C/C(=C\C=C\C=O)C(=O)c1ccc(Cl)cc1</smiles>

5d $(45 \%)$<smiles>C/C(=C\C=C(/C([NH3+])=O)c1ccccc1)C(=O)[C@H]1COC(C)(C)O1</smiles>
$5 \mathrm{~m}$-imin $(38 \%)$
Scheme 4. Rhodium-catalyzed reaction of allenones $\mathbf{2}$ with triazole $\mathbf{3 a}$ Controlled synthesis of 1,6-dicarbonyl derivatives $\mathbf{5}$.

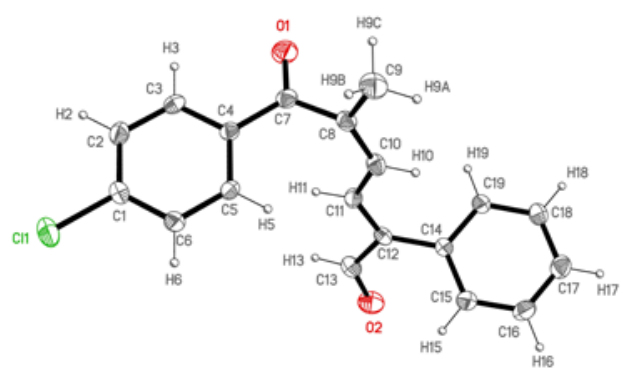

Figure 1. ORTEP drawing of (2Z,4E)-6-(4-chlorophenyl)-5-methyl-6-oxo-2phenylhexa-2,4-dienal $\mathbf{5 d}$. Thermal ellipsoids shown at 50\% probability.

A plausible mechanistic proposal for the rhodium-catalyzed formation of 2-pyrrolines 4 from allenols 1 and $\mathrm{N}$-sulfonyl-1,2,3triazoles $\mathbf{3}$ is depicted in Scheme 5 . Initially, reaction of the
$\mathrm{Rh}_{2}$ (oct) ${ }_{4}$ catalyst with the appropriate $\mathrm{N}$-sulfonyl-1,2,3-triazole $\mathbf{3}$, which is in equilibrium with its a-imino tautomer $\mathbf{6}$, results in the formation of an a-imino $\mathrm{Rh}(\mathrm{II})$-carbene $\mathbf{7}$ after extrusion of dinitrogen. Nucleophilic addition of the internal double bond of the cumullene moiety in allenols $\mathbf{1}$ to rhodacarbenes $\mathbf{7}$ formed zwitterions 8. Species 8 suffer a regioselective azacyclization reaction through attack of the imine moiety towards the positively charged allylic carbon atom to give 2-pyrrolines $\mathbf{4}$ with concurrent regeneration of the rhodium(II) catalyst. ${ }^{[10]}$

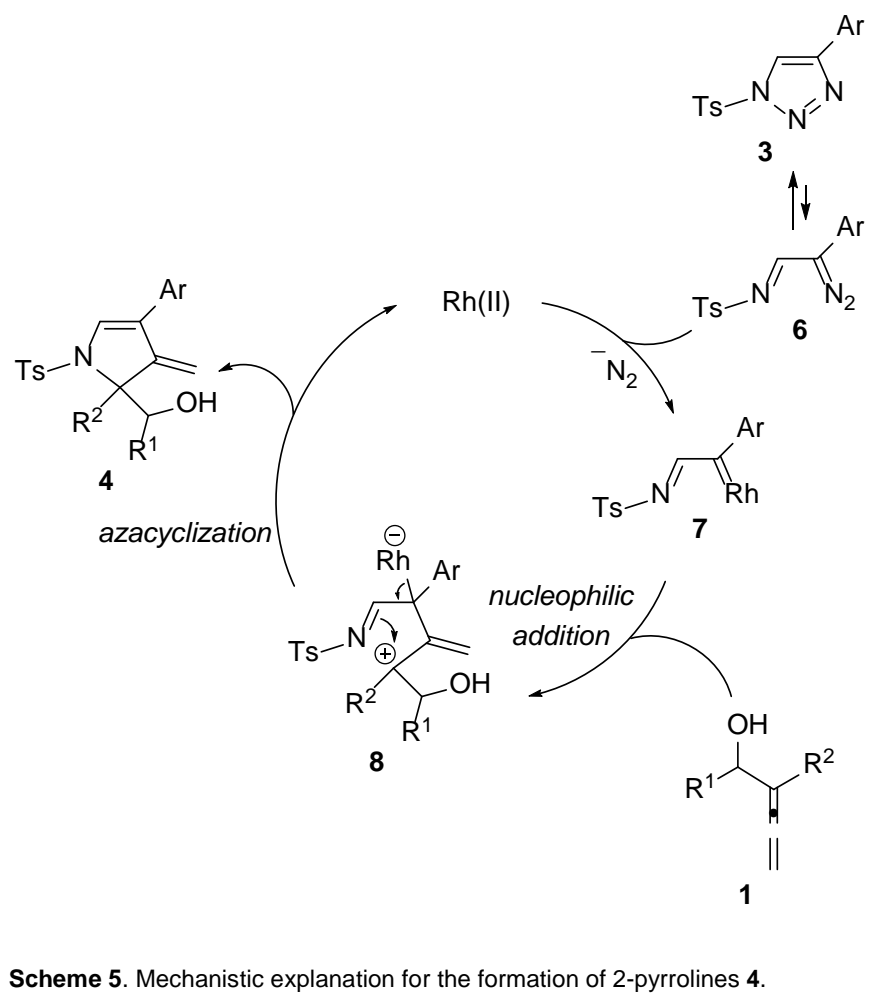

A tentative mechanistic proposal for the generation of 6-oxohexa-2,4-dienals 5 from allenones $\mathbf{2}$ and $\mathrm{N}$-sulfonyl-1,2,3-triazole 3a under $\mathrm{Rh}_{2}$ (oct) ${ }_{4}$ catalysis is summarized in Scheme 6. The required formation of the a-imino $\mathrm{Rh}$ (II)-carbene 7 occurs in the same way that above. However, replacing the allenol by an allenone resulted in a switch of the reactivity. A positional selectivity reversal should occur by attack of the terminal double bond of the allenone 2 to the electrophilic center of the rhodacarbene 7 . In this way, it may be formed zwitterionic species $\mathbf{9}$, which suffer a 1,2-hydride shift to its isomeric zwitterion $\mathbf{1 0}$, which rapidly evolves to the 1,6-dicarbonyl derivative $\mathbf{5}$ after release of the metal catalyst. The unforeseen isolation of imine $5 \mathrm{~m}$ imin from allenone $\mathbf{2 m}$ may reforce the pathway depicted in Scheme 6 . An alternative mechanistic possibility to the attack of the electrophilic carbon of compound 7 to the end of the allene, which should be contemplated, is an initial cyclopropanation of the terminal double bond of the allene. ${ }^{[11]}$ 


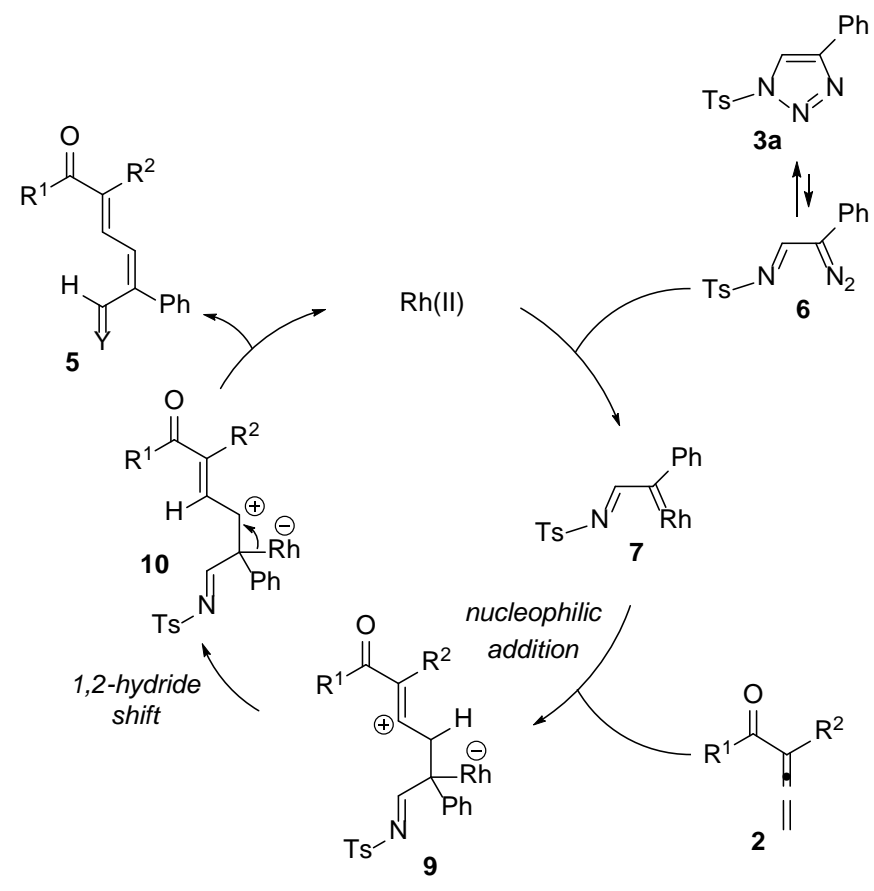

Scheme 6. Mechanistic explanation for the formation of 6-oxo-hexa-2,4-dienals 5.

\section{Conclusion}

In conclusion, we report that the divergent reaction of 1benzenesulfonyl-4-aryl-1,2,3-triazoles with functionalized allenes has selectively afforded 2-pyrrolines and 6-oxo-hexa-2,4-dienals. The rhodium-catalyzed reactions between allenols and 1benzenesulfonyl-4-aryl-1,2,3-triazoles yielded 2-pyrrolines, while a reactivity switch took place when the allene-tethered alcohol substrate was replaced by its ketone counterpart. Thus, acyclic 6oxo-hexa-2,4-dienals were stereoselectively formed as $(2 Z, 4 E)$ isomers when the rhodium-catalyzed reaction of 1benzenesulfonyl-4-phenyl-1,2,3-triazole was performed with allenones. Items for future study of this reactivity switch comprise the analysis of additional factors which influence the reaction outcome, election of different allene substrates, and mechanistic details.

\section{Experimental Section}

General methods: ${ }^{1} \mathrm{H}$ NMR and ${ }^{13} \mathrm{C}$ NMR spectra were recorded on a Bruke Avance-300 or Varian VRX-300S. NMR spectra were recorded in $\mathrm{CDCl}_{3}$ or $\mathrm{C}_{6} \mathrm{D}_{6}$ solutions, except otherwise stated. Chemical shifts are given in ppm relative to TMS $\left({ }^{1} \mathrm{H}, 0.0 \mathrm{ppm}\right)$, or $\mathrm{CDCl}_{3}\left({ }^{1} \mathrm{H}, 7.27 \mathrm{ppm} ;{ }^{13} \mathrm{C}, 76.9 \mathrm{ppm}\right)$, or $\mathrm{C}_{6} \mathrm{D}_{6}\left({ }^{1} \mathrm{H}, 7.16\right.$ $\left.\mathrm{ppm} ;{ }^{13} \mathrm{C}, 128.0 \mathrm{ppm}\right)$. Low and high resolution mass spectra were taken on an AGILENT 6520 Accurate-Mass QTOF LC/MS spectrometer using the electronic impact (EI) or electrospray modes (ES) unless otherwise stated. IR spectra were recorded on a Bruker Tensor 27 spectrometer. X-Ray crystallographic data were collected on a Bruker Smart CCD difractomer using graphite-monochromated Mo-K $\alpha$ radiation $(\lambda=0.71073 \AA$ ) operating at $50 \mathrm{Kv}$ and $35 \mathrm{~mA}$ with an exposure of $30.18 \mathrm{~s}$ in $\omega$. Specific rotation $[\alpha]_{D}$ is given in $10^{-1} \mathrm{deg} \mathrm{cm}^{2} \mathrm{~g}^{-1}$ at $20^{\circ} \mathrm{C}$, and the concentration (c) is expressed in $\mathrm{g}$ per $100 \mathrm{~mL}$. All commercially available compounds were used without further purification.

General procedure for the synthesis of 2-pyrrolines 4. $\mathrm{Rh}_{2}(\mathrm{Oct})_{4}(0.001$ $\mathrm{mmol})$ and the appropriate triazole $3(0.10 \mathrm{mmol})$ were added to a stirred solution of the corresponding allenol $\mathbf{1}(0.11 \mathrm{mmol})$ in toluene $(1.0 \mathrm{~mL})$ under argon. The resulting mixture was stirred under argon atmosphere at reflux temperature until disappearance of the starting material (TLC). After filtration through a pad of Celite, the mixture was extracted with ethyl acetate $(3 \times 3 \mathrm{~mL})$, and the combined extracts were washed twice with brine. The organic layer was dried $\left(\mathrm{MgSO}_{4}\right)$ and concentrated under reduced pressure. Chromatography of the residue eluting with hexanes/ethyl acetate mixtures gave analytically pure compounds. Spectroscopic and analytical data for 2-pyrrolines 4 follow. ${ }^{[12]}$

2-Pyrroline 4ba. From $51 \mathrm{mg}(0.30 \mathrm{mmol})$ of allenol $\mathbf{1 b}$, and after flash chromatography of the residue using hexanes/ethyl acetate (6:1) as eluent gave compound 4 ba (92 mg, 69\%) as a colorless oil; ${ }^{1} \mathrm{H}$ NMR $\left(300 \mathrm{MHz}, \mathrm{C}_{6} \mathrm{D}_{6}, 25^{\circ} \mathrm{C}\right.$ ): $\delta=7.77(\mathrm{~m}, 4 \mathrm{H}, \mathrm{Ar}), 7.33(\mathrm{~s}, 1 \mathrm{H},=\mathrm{CH}), 7.22(\mathrm{~d}, 1 \mathrm{H}, \mathrm{J}=8.1 \mathrm{~Hz}, \mathrm{Ar}), 7.00(\mathrm{~d}, 2 \mathrm{H}$, $\mathrm{J}=8.2 \mathrm{~Hz}, \mathrm{Ar}), 6.90(\mathrm{~m}, 3 \mathrm{H}, \mathrm{Ar}), 6.61(\mathrm{~d}, 2 \mathrm{H}, \mathrm{J}=8.0 \mathrm{~Hz}, \mathrm{Ar}), 6.13(\mathrm{br} \mathrm{s}, 1 \mathrm{H}, \mathrm{OCH})$, $5.02(\mathrm{~s}, 1 \mathrm{H},=\mathrm{CHH}), 4.93(\mathrm{~s}, 1 \mathrm{H},=\mathrm{CHH}), 2.12(\mathrm{~s}, 3 \mathrm{H}, \mathrm{Me}), 1.81(\mathrm{~s}, 3 \mathrm{H}, \mathrm{Me}), 1.76$ (s, 3H, Me); ${ }^{13} \mathrm{C}$ NMR $\left(75 \mathrm{MHz}, \mathrm{C}_{6} \mathrm{D}_{6}, 25^{\circ} \mathrm{C}\right): \delta=195.5,146.1,142.9,138.5$, 136.8, 135.2, 135.1, 134.0, 133.4 (=CH), 129.9 (Ar, 2CH), 129.5 ( $\mathrm{Ar}, 2 \mathrm{CH}), 129.2$ $(\mathrm{Ar}, 2 \mathrm{CH}), 128.7(\mathrm{Ar}, 2 \mathrm{CH}), 128.6(\mathrm{Ar}, \mathrm{CH}), 128.3(\mathrm{Ar}, 2 \mathrm{CH}), 127.8(\mathrm{Ar}, 2 \mathrm{CH})$, $117.7\left(=\mathrm{CH}_{2}\right), 59.9(\mathrm{OCH}), 21.2(\mathrm{Me}), 21.0(\mathrm{Me}), 16.2(\mathrm{Me})$; IR $\left(\mathrm{CHCl}_{3}\right): v=3279$, 1684, $1594 \mathrm{~cm}^{-1}$; HRMS (ES): calcd for $\mathrm{C}_{27} \mathrm{H}_{27} \mathrm{NO}_{3} \mathrm{~S}\left[\mathrm{M}+\mathrm{H}^{+}:\right.$:446.1790; found: 446.1773 .

2-Pyrroline 4ca. From $67 \mathrm{mg}(0.28 \mathrm{mmol})$ of allenol 1c, and after flash chromatography of the residue using hexanes/ethyl acetate (6:1) as eluent gave compound 4ca (85 mg, 60\%) as a colorless oil; ${ }^{1} \mathrm{H}$ NMR $\left(300 \mathrm{MHz}, \mathrm{C}_{6} \mathrm{D}_{6}, 25{ }^{\circ} \mathrm{C}\right.$ ): $\delta=7.56(\mathrm{~d}, 2 \mathrm{H}, \mathrm{J}=8.3 \mathrm{~Hz}, \mathrm{Ar}), 7.41(\mathrm{~d}, 2 \mathrm{H}, \mathrm{J}=8.0 \mathrm{~Hz}, \mathrm{Ar}), 7.35$ (dd, $1 \mathrm{H}, \mathrm{J}=8.3$, $1.2 \mathrm{~Hz}, \mathrm{Ar}), 7.23(\mathrm{~m}, 1 \mathrm{H}, \mathrm{Ar}), 7.10(\mathrm{~m}, 2 \mathrm{H}, \mathrm{Ar}), 7.02(\mathrm{~d}, 3 \mathrm{H}, \mathrm{J}=8.0 \mathrm{~Hz}, \mathrm{Ar}), 6.94$ $(\mathrm{m}, 3 \mathrm{H}, \mathrm{Ar}), 6.75(\mathrm{t}, 2 \mathrm{H}, \mathrm{J}=7.9 \mathrm{~Hz}, \mathrm{Ar}), 6.53(\mathrm{~s}, 1 \mathrm{H},=\mathrm{CH}), 6.47(\mathrm{~d}, 2 \mathrm{H}, \mathrm{J}=8.0$ $\mathrm{Hz}, \mathrm{Ar}), 5.80(\mathrm{~s}, 1 \mathrm{H}, \mathrm{OCH}), 5.61(\mathrm{~s}, 1 \mathrm{H},=\mathrm{CHH}), 5.25(\mathrm{~s}, 1 \mathrm{H},=\mathrm{CHH}), 2.11(\mathrm{~s}, 3 \mathrm{H}$, $\mathrm{Me}), 1.65$ (s, 3H, Me); ${ }^{13} \mathrm{C}$ NMR $\left(75 \mathrm{MHz}, \mathrm{C}_{6} \mathrm{D}_{6}, 25^{\circ} \mathrm{C}\right): \delta=197.5,142.9,142.4$, 141.4, 139.4, 138.0, 137.6, 135.8, 134.2, $133.4(=\mathrm{CH}), 131.3(\mathrm{Ar}, \mathrm{CH}), 129.6(\mathrm{Ar}$, 2CH), 129.5 ( $\mathrm{Ar}, 2 \mathrm{CH}), 129.1(\mathrm{Ar}, 2 \mathrm{CH}), 128.9(\mathrm{Ar}, 2 \mathrm{CH}), 128.6(\mathrm{Ar}, 2 \mathrm{CH}), 128.4$ $(\mathrm{Ar}, 2 \mathrm{CH}), 128.2(\mathrm{Ar}, \mathrm{CH}), 127.9(\mathrm{Ar}, 2 \mathrm{CH}), 127.7(\mathrm{Ar}, 2 \mathrm{CH}), 121.3\left(=\mathrm{CH}_{2}\right), 59.6$ (OCH), $21.2(\mathrm{Me}), 20.9(\mathrm{Me})$; IR $\left(\mathrm{CHCl}_{3}\right): \mathrm{v}=3280,1685,1595 \mathrm{~cm}^{-1}$; HRMS (ES): calcd for $\mathrm{C}_{32} \mathrm{H}_{29} \mathrm{NO}_{3} \mathrm{~S}[\mathrm{M}+\mathrm{H}]^{+}$: 508.1946; found: 508.1940 .

2-Pyrroline 4la. From $95 \mathrm{mg}(0.40 \mathrm{mmol})$ of allenol $\mathbf{1}$, and after flash chromatography of the residue using hexanes/ethyl acetate (8:1) as eluent gave compound $4 \mathrm{la}$ (99 mg, 48\%) as a colorless oil; ${ }^{1} \mathrm{H}$ NMR $\left(300 \mathrm{MHz}, \mathrm{C}_{6} \mathrm{D}_{6}, 25{ }^{\circ} \mathrm{C}\right.$ ): $\delta=7.68(\mathrm{t}, 4 \mathrm{H}, \mathrm{J}=8.2 \mathrm{~Hz}, \mathrm{Ar}), 7.05(\mathrm{~m}, 10 \mathrm{H}, \mathrm{Ar}), 6.91(\mathrm{~m}, 3 \mathrm{H}, \mathrm{Ar}), 6.60(\mathrm{~d}, 2 \mathrm{H}$, $J=7.9 \mathrm{~Hz}, \mathrm{Ar}), 6.06(\mathrm{~d}, 1 \mathrm{H}, \mathrm{J}=8.5 \mathrm{~Hz},=\mathrm{CH}), 5.96(\mathrm{~d}, 1 \mathrm{H}, \mathrm{J}=8.5 \mathrm{~Hz}, \mathrm{OCH}), 4.98$ $(\mathrm{s}, 1 \mathrm{H},=\mathrm{CHH}), 4.75(\mathrm{~s}, 1 \mathrm{H},=\mathrm{CHH}), 3.22\left(\mathrm{~m}, 2 \mathrm{H},=\mathrm{CH}_{2}\right), 1.78(\mathrm{~s}, 3 \mathrm{H}, \mathrm{Me}) ;{ }^{13} \mathrm{C}$ NMR $\left(75 \mathrm{MHz}, \mathrm{C}_{6} \mathrm{D}_{6}, 25^{\circ} \mathrm{C}\right): \delta=195.2,145.6,142.8,140.7,140.5,138.6,138.5$, 135.0, $133.5(=\mathrm{CH}), 130.0(\mathrm{Ar}, 2 \mathrm{CH}), 129.9(\mathrm{Ar}, 2 \mathrm{CH}), 129.6(\mathrm{Ar}, 2 \mathrm{CH}), 129.5(\mathrm{Ar}$, 2CH), $128.8(\mathrm{Ar}, 2 \mathrm{CH}), 128.7(\mathrm{Ar}, 2 \mathrm{CH}), 128.6(\mathrm{Ar}, 2 \mathrm{CH}), 128.5(\mathrm{Ar}, 2 \mathrm{CH}), 127.6$ (Ar, 2CH), $126.4(\mathrm{Ar}, \mathrm{CH}), 120.9\left(=\mathrm{CH}_{2}\right), 60.0(\mathrm{OCH}), 36.1\left(\mathrm{CH}_{2}\right), 21.0(\mathrm{Me})$; IR $\left(\mathrm{CHCl}_{3}\right): v=3279,1686,1595 \mathrm{~cm}^{-1}$; HRMS (ES): calcd for $\mathrm{C}_{32} \mathrm{H}_{30} \mathrm{NO}_{3} \mathrm{~S}[\mathrm{M}+$ $\mathrm{H}^{+}$: 508.1941; found: 508.1949.

2-Pyrroline 4ma. From $100 \mathrm{mg}(0.54 \mathrm{mmol})$ of allenol $\mathbf{1 m}$, and after flash chromatography of the residue using hexanes/ethyl acetate (3:1) as eluent gave compound $4 \mathrm{ma}(100 \mathrm{mg}, 41 \%)$ as a colorless oil; $[\alpha]_{D}^{20}=+16.7\left(c 0.3\right.$ in $\left.\mathrm{CHCl}_{3}\right)$; ${ }^{1} \mathrm{H}$ NMR $\left(300 \mathrm{MHz}, \mathrm{C}_{6} \mathrm{D}_{6}, 25^{\circ} \mathrm{C}\right): \delta=7.76(\mathrm{~d}, 2 \mathrm{H}, \mathrm{J}=8.3 \mathrm{~Hz}, \mathrm{Ar}), 7.72(\mathrm{~d}, 2 \mathrm{H}, \mathrm{J}$ $=7.1 \mathrm{~Hz}, \mathrm{Ar}), 6.93(\mathrm{~m}, 3 \mathrm{H}, \mathrm{Ar}), 6.68(\mathrm{~d}, 2 \mathrm{H}, \mathrm{J}=8.5 \mathrm{~Hz}, \mathrm{Ar}), 6.16(\mathrm{~d}, 1 \mathrm{H}, \mathrm{J}=8.8$ 
$\mathrm{Hz}, \mathrm{OH}), 6.02(\mathrm{~d}, 1 \mathrm{H}, \mathrm{J}=7.3 \mathrm{~Hz},=\mathrm{CH}), 5.91(\mathrm{~d}, 1 \mathrm{H}, \mathrm{J}=8.6 \mathrm{~Hz}, \mathrm{OCH}), 4.92(\mathrm{~s}$, $1 \mathrm{H},=\mathrm{CHH}), 4.90(\mathrm{~s}, 1 \mathrm{H},=\mathrm{CHH}), 4.67(\mathrm{q}, 1 \mathrm{H}, \mathrm{J}=7.5 \mathrm{~Hz}, \mathrm{OCH}), 3.88(\mathrm{t}, 1 \mathrm{H}, \mathrm{J}=$ $7.7 \mathrm{~Hz}, \mathrm{CHH}$ ), 3.50 (t, $1 \mathrm{H}, \mathrm{J}=7.7 \mathrm{~Hz}, \mathrm{CHH}), 1.80$ (s, 3H, Me), 1.52 (s, 3H, Me) 1.47 (s, 3H, Me), 1.38 (s, 3H, Me); ${ }^{13} \mathrm{C}$ NMR (75 MHz, $\left.\mathrm{C}_{6} \mathrm{D}_{6}, 25^{\circ} \mathrm{C}\right): \delta=195.4$ 145.7, 142.9, 138.6, 137.0, 135.0, 133.5 (=CH), $129.3(\mathrm{Ar}, 2 \mathrm{CH}), 128.5(\mathrm{Ar}, 2 \mathrm{CH})$, $128.4(\mathrm{Ar}, 2 \mathrm{CH}), 128.0(\mathrm{Ar}, \mathrm{CH}), 127.5(\mathrm{Ar}, 2 \mathrm{CH}), 118.1\left(=\mathrm{CH}_{2}\right), 109.4,73.4$ $(\mathrm{OCH}), 69.6\left(\mathrm{OCH}_{2}\right), 60.2(\mathrm{OCH}), 27.0(\mathrm{Me}), 26.3(\mathrm{Me}), 21.0(\mathrm{Me}), 15.4(\mathrm{Me})$; IR $\left(\mathrm{CHCl}_{3}\right): v=3281,1685,1593 \mathrm{~cm}^{-1}$; HRMS (ES): calcd for $\mathrm{C}_{25} \mathrm{H}_{33} \mathrm{~N}_{2} \mathrm{O}_{5} \mathrm{~S}[\mathrm{M}+$ $\left.\mathrm{NH}_{4}\right]^{+}:$473.2105; found: 473.2114 .

General procedure for the synthesis of 6-oxo-hexa-2,4-dienals 5. $\mathrm{Rh}_{2}(\mathrm{Oct})_{4}$ $(0.001 \mathrm{mmol})$ and the appropriate triazole $3(0.10 \mathrm{mmol})$ were added to a stirred solution of the corresponding allenone $2(0.11 \mathrm{mmol})$ in choroform $(1.0 \mathrm{~mL})$ under argon. The resulting mixture was stirred under argon atmosphere at reflux temperature until disappearance of the starting material (TLC). After filtration through a pad of Celite, the mixture was extracted with ethyl acetate $(3 \times 3 \mathrm{~mL})$, and the combined extracts were washed twice with brine. The organic layer was dried $\left(\mathrm{MgSO}_{4}\right)$ and concentrated under reduced pressure. Chromatography of the residue eluting with hexanes/ethyl acetate mixtures gave analytically pure compounds. Spectroscopic and analytical data 6-oxo-hexa-2,4-dienals 5 follow.

6-Oxo-hexa-2,4-dienal 5a. From $40 \mathrm{mg}(0.25 \mathrm{mmol})$ of allenone 1a, and after flash chromatography of the residue using hexanes/ethyl acetate $(10: 1)$ as eluent gave compound $\mathbf{5 a}$ (33 mg, 47\%) as a colorless oil; ${ }^{1} \mathrm{H}$ NMR $\left(300 \mathrm{MHz}, \mathrm{C}_{6} \mathrm{D}_{6}\right.$, $25^{\circ} \mathrm{C}$ ): $\delta=8.93(\mathrm{~s}, 1 \mathrm{H}, \mathrm{CHO}), 7.84(\mathrm{~d}, 2 \mathrm{H}, \mathrm{J}=8.4 \mathrm{~Hz}, \mathrm{Ar}), 7.19(\mathrm{~m}, 3 \mathrm{H}, \mathrm{Ar}), 7.08$ $(\mathrm{m}, 5 \mathrm{H}, \mathrm{Ar}), 6.74(\mathrm{~d}, 1 \mathrm{H}, \mathrm{J}=12.0 \mathrm{~Hz},=\mathrm{CH}), 6.45$ (dd, $1 \mathrm{H}, \mathrm{J}=12.0,1.5 \mathrm{~Hz},=\mathrm{CH})$, $1.60(\mathrm{~d}, 3 \mathrm{H}, \mathrm{J}=1.3 \mathrm{~Hz}, \mathrm{Me}) ;{ }^{13} \mathrm{C}$ NMR $\left(75 \mathrm{MHz}, \mathrm{C}_{6} \mathrm{D}_{6}, 25^{\circ} \mathrm{C}\right): \delta=197.9(\mathrm{CO})$, $192.0(\mathrm{CHO}), 148.0,143.0(=\mathrm{CH}), 142.7,136.3,133.9(\mathrm{Ar}, \mathrm{CH}), 132.8,130.5$ (Ar, 2CH), $129.6(\mathrm{Ar}, 2 \mathrm{CH}), 129.2(\mathrm{Ar}, 2 \mathrm{CH}), 128.5(\mathrm{Ar}, 2 \mathrm{CH}), 128.4(\mathrm{Ar}, \mathrm{CH}), 126.4$ $(=\mathrm{CH}), 21.8(\mathrm{Me})$; IR $\left(\mathrm{CHCl}_{3}\right): v=1704,1689,1655,1619 \mathrm{~cm}^{-1}$; HRMS (ES): calcd for $\mathrm{C}_{19} \mathrm{H}_{16} \mathrm{O}_{2}[M+\mathrm{H}]^{+}:$277.1223; found: 277.1221 .

6-Oxo-hexa-2,4-dienal 5c. From $33 \mathrm{mg}(0.14 \mathrm{mmol})$ of allenone $1 \mathrm{c}$, and after flash chromatography of the residue using hexanes/ethyl acetate (10:1) as eluent gave compound $5 \mathrm{c}$ (37 mg, 72\%) as a colorless oil; ${ }^{1} \mathrm{H}$ NMR $\left(300 \mathrm{MHz}, \mathrm{C}_{6} \mathrm{D}_{6}\right.$, $\left.25^{\circ} \mathrm{C}\right): \delta=9.02(\mathrm{~s}, 1 \mathrm{H}, \mathrm{CHO}), 7.98(\mathrm{~d}, 2 \mathrm{H}, \mathrm{J}=8.2 \mathrm{~Hz}, \mathrm{Ar}), 7.22(\mathrm{~m}, 4 \mathrm{H}, \mathrm{Ar}), 7.21$ $(\mathrm{d}, 1 \mathrm{H}, \mathrm{J}=12.0 \mathrm{~Hz},=\mathrm{CH}), 7.12(\mathrm{~m}, 4 \mathrm{H}, \mathrm{Ar}), 7.05(\mathrm{~d}, 1 \mathrm{H}, \mathrm{J}=12.0 \mathrm{~Hz},=\mathrm{CH}), 6.86$ $(\mathrm{m}, 2 \mathrm{H}, \mathrm{Ar}), 6.84$ (t, 2H, J = 7.9 Hz, Ar), 1.91 (s, 3H, Me); ${ }^{13} \mathrm{C}$ NMR $(75 \mathrm{MHz}$, $\left.\mathrm{C}_{6} \mathrm{D}_{6}, 25^{\circ} \mathrm{C}\right): \delta=196.4(\mathrm{CO}), 191.9(\mathrm{CHO}), 150.1,145.2,144.0,143.0(=\mathrm{CH})$, 136.5, 134.8, 132.7, 130.7 ( $\mathrm{Ar}, 2 \mathrm{CH}), 130.2(\mathrm{Ar}, 2 \mathrm{CH}), 130.0(\mathrm{Ar}, 2 \mathrm{CH}), 129.5$ (Ar, CH), 129.3 (Ar, 2CH), 128.5 (Ar, 2CH), 128.4 (Ar, CH), $126.9(\mathrm{Ar}, 2 \mathrm{CH}), 124.3$ $(=\mathrm{CH}), 21.4(\mathrm{Me})$; IR $\left(\mathrm{CHCl}_{3}\right): v=1712,1684,1652,1612 \mathrm{~cm}^{-1}$; HRMS (ES): calcd for $\mathrm{C}_{25} \mathrm{H}_{20} \mathrm{O}_{2}[M+\mathrm{H}]^{+}$: 353.1536; found: 353.1543 .

\section{Acknowledgements}

Financial support from the MINECO and FEDER (Projects CTQ2015-65060-C2-1-P and CTQ2015-65060-C2-2-P) is gratefully acknowledged. S. C. thanks MEC for a predoctoral contract. We thank Dr. M. R. Torres for X-ray analysis.

Keywords: allenes • enones • heterocycles • regioselectivity • synthetic methods

[1] For selected recent reviews, see: a) Y. Jiang, R. Sun, X.-Y. Tang, M. Shi, Chem. Eur. J. 2016, 22, 17910; b) Y. Wang, X. Lei, Y. Tang, Synlett 2015, 26, 2051; c) H. M. L. Davies, J. S. Alford, Chem. Soc. Rev. 2014, 43, 5151 d) P. Anbarasan, D. Yadagiri, S. Rajasekar, Synthesis 2014, 46, 3004; e) A. V. Gulevich, V. Gevorgyan, Angew. Chem. 2013, 125, 1411;
Angew. Chem. Int. Ed. 2013, 52, 1371; f) B. Chattopadhyay, V. Gevorgyan Angew. Chem. 2012, 124, 886; Angew. Chem. Int. Ed. 2012, 51, 862.

[2] For selected reviews, see: a) W. Yang, A. S. K. Hashmi, Chem. Soc. Rev. 2014, 43, 2941; b) S. Kitagaki, F. Inagaki, C. Mukai, Chem. Soc. Rev. 2014 43, 2956; c) T. Cañeque, F. M. Truscott, R. Rodríguez, G. Maestri, M. Malacria, Chem. Soc. Rev. 2014, 43, 2916; d) T. Lechel, F. Pfrengle, H.U. Reissig, R. Zimmer, ChemCatChem 2013, 5, 2100; e) S. Yu, S. Ma, Angew. Chem. 2012, 124, 3128; Angew. Chem. Int. Ed. 2012, 51, 3074 f) N. Krause, C. Winter, Chem. Rev. 2011, 111, 1994; g) B. Alcaide, P. Almendros, Adv. Synth. Catal. 2011, 353, 2561; h) S. Ma, Chem. Rev. 2005, 105, 2829; i) A. S. K. Hashmi, Angew. Chem. 2000, 112, 3737; Angew. Chem. Int. Ed. 2000, 39, 3590; j) Y. Yu, W. Yang, F. Rominger, A. S. K. Hashmi, Angew. Chem. 2013, 125, 7735; Angew. Chem. Int. Ed. 2013, 52, 7586; k) R. L. Melen, L. C. Wilkins, B. M. Kariuki, H. Wadepohl, L. H. Gade, A. S. K. Hashmi, D. W. Stephan, M. M. Hansmann, Organometallics, 2015, 34, 4127

[3] a) Intramolecular version: E. E. Schultz, R. Sarpong, J. Am. Chem. Soc. 2013, 135, 4696; b) Intermolecular version: T. Miura, K. Hiraga, T. Biyajima, T. Nakamuro, M. Murakami, Org. Lett. 2013, 15, 3298; c) Rearrangement: T. Miura, T. Nakamuro, T. Biyajima, M. Murakami, Chem. Lett. 2015, 44, 700.

[4] B. Alcaide, P. Almendros, T. Martínez del Campo, E. Soriano, J. L. MarcoContelles, Chem. Eur. J. 2009, 15, 1901.

[5] B. Alcaide, P. Almendros, T. Martínez del Campo, Eur. J. Org Chem. 2007, 2844.

[6] For selected reviews, see: a) J. Le Bras, J. Muzart, Chem. Soc. Rev. 2014 43, 3003; b) M. P. Muñoz, Chem. Soc. Rev. 2014, 43, 3164. For a selected contribution, see: c) A. S. K. Hashmi, M. C. Blanco, D. Fischer, J. W. Bats, Eur. J. Org. Chem. 2006, 1387

[7] a) J. A. Marshall, E. D. Robinson, J. Org. Chem. 1990, 55, 3450; b) J. A Marshall, G. S. Bartley, J. Org. Chem. 1994, 59, 7169; c) J. A. Marshall, E. M. Wallace, J. Org. Chem. 1995, 60, 796; d) A. S. K. Hashmi, Angew. Chem. 1995, 107, 1749; Angew. Chem. Int. Ed. Engl. 1995, 34, 1581; e) A. S. K. Hashmi, T. L. Ruppert, T. Knöfel, J. W. Bats, J. Org. Chem. 1997, 62, 7295; f) A. S. K. Hashmi, J.-H. Choi, J. W. Bats, J. Prakt. Chem. 1999 341,$342 ;$ g) A. S. K. Hashmi, L. Schwarz, J. W. Bats, J. Prakt. Chem. 2000 342,$40 ;$ h) A. S. K. Hashmi, L. Schwarz, J. H. Choi, T. M. Frost, Angew. Chem. 2000, 112, 2382; Angew. Chem. Int. Ed. 2000, 39, 2285; i) A. S. K. Hashmi, L. Schwarz, M. Bolte, Eur. J. Org. Chem. 2004, 1923; j) C.-Y. Zhou, P. W. H. Chan, C.-M. Che, Org. Lett. 2006, 8, 325; k) A. S. K. Hashmi, L. Schwarz, Chem. Ber./Recueil 1997, 130, 1449; also other carbonyl groups lead to cyclization: I) A. S. K. Hashmi, A. M. Schuster, S. Litters, F. Rominger, M. Pernpointner, Chem. Eur. J. 2011, 17, 5661.

[8] The carbonyl moiety is an important functionality present in severa bioactive compounds, which have been widely used in synthetic organic chemistry based on its chameleonic reactivity. Several methodologies for the preparation of 1,3-, 1,4- and 1,5-dicarbonyl derivatives have been developed; but, the preparation of the 1,6-dicarbonyl counterpart is more troublesome. For a recent strategy for 1,6-dicarbonyl synthesis, see: X. Chen, X. Liu, J. T. Mohr, J. Am. Chem. Soc. 2016, 138, 6364.

[9] CCDC 1413458 contains the supplementary crystallographic data for compound $\mathbf{5 d}$ in this paper (www.ccdc.cam.ac.uk/data_request/cif).

[10] If this mechanistic picture is operative, cyclization of intermediates 8 could also occur at another terminus of the allyl cation moiety leading to pyrroles. However, we did not observe the formation of pyrroles. Final products, 2 pyrrolines $\mathbf{4}$, are stable under the reaction conditions, despite that the undetected pyrroles seem thermodynamically more stable.

[11] According to reference [3c], it is expected to afford methylenecyclopropane intermediates. However, we were not able to detect the formation of these species as byproducts.

[12] Experimental procedures as well as full spectroscopic and analytical data for compounds not included in this Experimental Section are described in the Supporting Information. It contains compound characterization data, experimental procedures, and copies of NMR spectra for all new compounds. 
Received: ((will be filled in by the editorial staff))

Revised: ((will be filled in by the editorial staff))

Published online: ((will be filled in by the editorial staff)) 
Entry for the Table of Contents

\section{FULL PAPER}

The rhodium-catalyzed reaction of 1 benzenesulfonyl-4-aryl-1,2,3-triazoles with functionalized allenes, namely allenols and allenones, has selectively afforded in a divergent way, 2-

pyrrolines and 6-oxo-hexa-2,4-dienals.

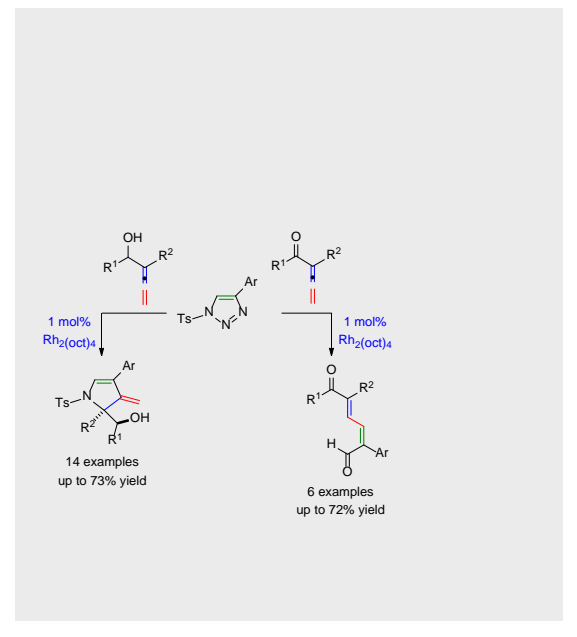

Synthetic Methods

Benito Alcaide, * Pedro Almendros, * Sara Cembellín, Teresa Martínez del Campo, and Guillermo Palop

Allenols versus Allenones: RhodiumCatalyzed Regiodivergent and Tunable Allene Reactivity with Triazoles

Autores (p.o. de firma): Alcaide, B.; Almendros, P.; Cembellín, S.; Martínez del Campo, T.; Palop, G.

Título: Allenols versus Allenones: Rhodium-Catalyzed Regiodivergent and Tunable Allene Reactivity with Triazoles

Revista: Chem. Eur. J. 2017, 23, 13754-13759; DOI: 10.1002/chem.201702468 